\title{
THE IMPACT OF CORPORATE REPUTATION AND INFORMATION SHARING ON VALUE CREATION FOR ORGANIZATIONAL CUSTOMERS
}

Vesna Žabkar, Maja Arslanagić-Kalajdžić *

\begin{abstract}
The importance of corporate communication to build, protect and maintain corporate reputation has been advocated in numerous publications in recent years. The main goal of this paper is to provide an understanding of the impact of corporate reputation and information sharing on value creation. Both reputation and information sharing represent signals that customers observe in the process of value creation, which is seen as the end focus for corporate marketing. The paper draws on signaling theory and corporate marketing literature from the European and American schools of thought.

The empirical test of the hypothesized model focuses on the banking industry. Organizational customers from a South East European country shared their views about banks they currently cooperate with. The research instrument contained multi-item scales adapted from the existing literature. An analysis using structural equation modeling confirmed that corporate reputation positively and significantly influences customer perceived value. The effect of information sharing on customer perceived value is not direct but mediated by corporate reputation. This finding contributes to the existing discussion on the role of corporate reputation and communication as antecedents in the process of value creation.
\end{abstract}

Keywords: corporate communication, information sharing, corporate reputation, customer perceived value

JEL Classification: M30

\section{INTRODUCTION}

Many researchers have focused on different aspects and portions of creating value proposition for corporate stakeholders in the last couple of decades. Knowledge and tools for creating and improving stakeholders' perceived value have turned out to be highly desired in firms. Based on signaling theory (Spence 1973; Kirmani and Rao 2000), stakeholders are sensible to both strategic and uncontrolled signals sent by companies. Signals are regarded as "things... that would carry information persistently in equilibrium from sellers to buyers, or more generally from those with more to those with less information" (Spence 2002, p. 434). Signaling theory implicitly explains the situation in which a customer is faced with an investment decision under uncertainty, and therefore interprets differently the signals a company transmits, depending on his/her expectations and the market situation.
Several market models, each holding specific assumptions and dilemmas, are created in microeconomics using signaling theory (e.g. Vermaelen 1981; Banerjee and Gaston 2004). However, little is known about the role of market signaling for marketing discipline, particularly from the

* Vesna Žabkar, PhD
Professor
Marketing Department, Faculty of Economics Ljubljana
E-mail: vesna.zabkar@ef.uni-lj.si
Maja Arslanagić-Kalajdžić, MA
Senior Teaching Assistant
Marketing Department, School of Economics and
Business Sarajevo
E-mail: maja.arslanagic@efsa.unsa.ba


perspective of provider-customer relationships. One example is a theory on signaling an unobservable product quality (Wernerfelt 1988; Kirmani and Rao 2000), where reputation is acknowledged as important, together with other marketing-relevant signals.

This research regards decisions of organizational customers to choose a specific service company and to build and maintain a relationship with this company as a real investment decision that encompasses all risk elements. Therefore, the proposal is that sharing information through communication channels signals from supplier to customer. This proposal broadens the already acknowledged function of information sharing: an element of relational governance between the parties (Noordewier, George and Nevin 1990) to the new, signaling one. Information sharing is well researched and defined in the supply chain literature (e.g. Lee, So and Tang 2000), and it is seen as "... an important factor in a supply chain participant's expectation of maintaining relationship continuity..." (Tai and Ho 2000, p. 1387). Here information sharing is defined as "the extent to which the supplier openly shares information about the future that may be useful to the customer relationship" (Cannon and Homburg 2001, p. 32), as its role in the frame of signaling theory and its significance for the development of corporate communications is debated.

Conceptually, a wide framework of corporate marketing is analyzed (Balmer and Greyser 2006), where information sharing is regarded as one part of corporate communication. Corporate reputation and corporate communications are distinct elements of the corporate marketing mix (six C's), which should result in creating recognition and acceptance of the value proposition offered by a company. According to the stakeholder perspective (Freeman 1984; Donaldson and Preston 1995; Gummerson 2008; Frow and Payne 2011), companies need to balance between persons/ groups that have an interest in or influence corporate activities and persons/groups that are interesting to or influenced by companies. Within the present research, the focus is on a specific stakeholder group - organizational customers.

The aim of the paper is to examine the influence of two corporate marketing constructs, corporate reputation and information sharing on customer perceived value (CPV) in an organizational customer setting. Value perception is a concept that has greater importance and effects on organizational customers than on individual customers (Eggert and Ulaga 2002). Therefore, it is substantial to understand the way perceived value is related to other marketing constructs, especially to those contributing to its formation. We focus on service companies for which, due to the intangibility of services, customers face problems of service quality assessment before the purchase (Hansen, Samuelsen and Silseth 2008) and evaluation of service during the encounter and service delivery, e.g. due to a lack of knowledge. Our objective is to test to what degree corporate reputation and information sharing help customers in their assessment.

This research contributes to the existing literature on several grounds: (1) it interprets corporate marketing efforts (corporate reputation and information sharing) in terms of signaling theory, (2) it contributes to the discussion on relationships between customer perceived value and its antecedents and establishes the sequence of effects between these constructs, and (3) it offers empirical support for relationships analyzed.

We proceed with our paper as follows: based on a critical literature review we develop the conceptual framework for the research, present the research design for the empirical section of the paper and present our empirical findings. We conclude with a discussion and conclusions, together with implications and the limitations of our research.

\section{LITERATURE REVIEW}

\section{Information Sharing and Corporate Reputation in the Framework of Corporate Marketing}

The corporate marketing framework was first introduced by Balmer (1998), wherein several important constructs were placed under the same umbrella. They are presented through the corporate marketing mix, also known as the six C's (Balmer and Greyser 2006): character (corporate identity), culture (organizational identity), covenant (corporate branding), communication (corporate communications), conceptualizations (corporate reputation and corporate image), and constituencies (marketing and stakeholder management). Therefore, corporate marketing gathers multiple exchange relationships with multiple stakeholder groups and networks, both internally (e.g. with and between owners, managers and employees) and externally within various constituencies (Powell 2011). However, Balmer's proposals remain at the conceptual level. There is no empirical analysis that combines the elements of a corporate marketing framework and evaluates their role (neither internally, nor externally). These elements are of critical importance for this framework to "become alive" in practice. Our research makes one step in that direction.

Corporate reputation and corporate communication belong to two distinct elements of the corporate marketing mix. Corporate communication includes information sharing explained through the communication effect of management and employees (Balmer 2006; Balmer and Greyser 2006; Balmer 2009; Balmer 2011). The theoretical background for both concepts is outlined in the following paragraphs.

Corporate communication has several definitions and a very wide domain and scope. For Van Riel $(1995,26)$, corporate communication represents "an instrument of management by means of which all consciously used forms of internal and external communication are harmonized as effectively and efficiently as possible so as to create a favorable basis for relationships with groups upon which the company is dependent". In spite of such an explicit definition, the term communication is used with different prefixes: marketing communication, organizational communication or management communication (Christensen and Cornelissen 2010). It has been posed by different authors that corporate communication is a common term for 
all communication efforts (e.g. Shelby, 1993; Argenti, Howel and Beck 2005; Christensen and Cornelissen 2010). This is how Balmer (2009) explains one of his Cs and says that "corporate communications relates to the totality of controlled messages from the organization directed towards customers, employees and stakeholders."

As a specific form of communication, information sharing in organizational relationships is important to customers, particularly from the long-term, relational perspective (Noordewieret al. 1990). However, intensive discussion of information sharing still remains in the supply chain literature. Information sharing can be operational or strategic, and appears through internal or external flows of information and with various types of content. Research also shows that it should be aligned with business objectives and market orientation so that all parties can make profitable use of information sharing (Tiedemann, Van Birgele and Semeijn 2009; Tai and Ho 2010; Kolekofski and Heminger 2003). Therefore, information sharing is significant both to organizational suppliers and to organizational customers, and adds value to both the product/service and relationships. Several studies investigate this phenomenon in terms of inter-firm communication, commitment, relationships, customer satisfaction and customer loyalty intention (Krause 1999; Cannon and Perreault 1999; Tai 2011). The importance of information sharing is also analyzed through the evaluation of the need for investment in the ongoing organizational relationship (Jonsson and Lindbergh 2010). Tai (2011) analyzes different perspectives on the value of information sharing for organizational relationships. He concludes that companies benefit in terms of increased competitive advantage and performance, as well as in terms of alignment of decision making processes between the company and the organizational customer. On the other hand, information sharing can also provide significant cost savings for companies (Lee, So and Tang, 2000). Therefore, information sharing has an important role for both sides of the organizational relationship.

To the authors' knowledge, apart from one study (Hansen, Samuelsen and Silseth, 2008), there are no published or available empirical findings on the influence of information sharing on customer perceived value. Other research has also neglected the possible signaling power of information sharing per se. Information sharing was usually analyzed theoretically from the resource based view (as a competitive advantage) or from the relational perspective. Although we do not question the use of these established theories, we notice that the signaling potential of information sharing in services has been neglected. As service quality usually may not be observed prior to the purchase, and as clients are faced with information asymmetry, providers' openness in information sharing may help clients evaluate service quality and other service benefits, and hence contribute to the creation of value perception.

Information sharing was given additional importance and a new angle with the emergence of service-dominant logic (Vargo and Lusch 2004; 2007). Information flow is regarded as the primary flow and service is perceived as a provision of information to customers. Lusch, Vargo and Malter (2006) underline the focus on the symmetric exchanges within service-dominant logic. With this in mind, they state that information sharing should be symmetric and imply that "one does not mislead customers ... by not sharing relevant information that could enable them to make better and more informed choices..." (Lusch, Vargo and Malter 2006, 272). They also recognize two kinds of capabilities that companies should build: collaborative (working with others) and absorptive (absorbing new information from others). This is recognized in further discussions about the importance of information and knowledge sharing (Frow and Payne 2011).When it comes to services, customers are in constant need of information. They analyze information before the purchase, collect information during the service encounter and still follow all of the important events concerning the companies they relate to. Therefore, several issues should be clear for companies: the purposes of information sharing and its primary purpose; the type of information that should be shared with customers; when they should share information; and how the information should be delivered. Otherwise, the importance of information sharing is acknowledged by companies, although not actually implemented. Due to these characteristics, information sharing might not have the ability to bind to firms' performance as strong as other signals (Ippolito, 1990). However, as signaling costs may be regarded as relatively low for providers, they may quickly learn the benefits of information sharing. In this sense, questions related to information sharing are connected to customers' perceptions of value, which emerge through the relationship and service delivery process.

The second key concept in our research is corporate reputation. In the economic and business senses, the concept of corporate reputation was first introduced by Bourdieu (1986) in his seminal piece "The form of capital", where reputation was aligned with social capital as an "aggregate of the actual or potential resources which are linked to possession of a durable network of more or less institutionalized relationships of mutual acquaintance and recognition" (Bourdieu 1985). Among the many attempts to define corporate reputation, the definition offered by Fombrun and Van Riel $(1997,10)$ is the most frequently used: "Corporate reputation is a collective representation of a firm's past actions and results that describes the firm's ability to deliver valued outcomes to multiple stakeholders". Recently, Walker (2010, 370) added features to previous definitions and defined "overall corporate reputation as a relatively stable, issue specific, aggregate perceptual representation of a company's past actions and future prospects compared against some standard". This represents an important contribution to defining the overall characteristics of corporate reputation that came out of Walker's (2010) extensive review of new developments in the corporate reputation field. The new features of the definition could be regarded as the continuation of Fombrun's and Van Riel's definition in terms of time span, perceptions, relativity of reputation and the issues treated. However, it is obvious that the definition of overall reputation is not convenient for operationalization of any kind. Hardly any research could encompass all of the elements necessary to measure overall reputation. Current 
research usually takes one standpoint (e.g. perception of experts and managers when it comes to official formative rankings). We have made an attempt to do so by computing the reputation quotient (Fombrun, Gardberg, and Server 2000) as a multi-stakeholder measure.This research treats corporate reputation as it is perceived by organizational customers.

The importance of reputation is increased in services, especially in the pre-purchase phase, but also in maintaining relationships once they are already built (Zeithaml 1988; Stahl, Matzler and Hinterhuber 2003). Research shows that offers from a company that already has a good corporate reputation in the market are preferred over offers from an unknown company (Bengtsson and Servais 2005). This means that corporate reputation helps customers in evaluating alternatives before their purchase. Reputation is hence a well established signal with a strong bonding effect (Kirmani and Rao, 2000). When it comes to the purchase and post-purchase experience, it is advised that corporate reputation should be built by using current customers/ clients as spokespersons and therefore utilizing the effect of word-of-mouth. Relationships between current and potential customers, other stakeholders and corporate reputation are hence evident through network principles or by using so-called customer reference relationships (Helm and Salminen 2010). According to Fombrun (1996), services are goods based on trust and purchased based on reputation. Therefore, service companies should make creating, maintaining and defending their reputation one of their main strategic determinants.

When it comes to the previous research on reputation, much of it focused on the importance of customers and other stakeholders. Wiedmann and Buxel (2005) showed that the influence of the general public on corporate reputation has increased. One of the possible reasons for this could be in the increased speed of information flow in today's society. A wide range of different constructs was used in research on reputation, from the company's performance and strategic benefits to its effects on customer loyalty, satisfaction, word-of-mouth and search for alternatives (Fornell et al. 1996; Deephouse 2000; Helm 2007; Shamma and Hassan 2009; Walker 2010; and more). All of these efforts underline the importance of the corporate reputation construct within the corporate marketing framework. However, little research focuses on the relationship of corporate reputation with customer perception of value, which is the focus of this research.

\section{Customer Perceived Value in Organizational Relationships}

The customer value construct is regarded as one of the priorities in marketing research and practice. Although its importance has been recognized (Holbrook 1994; Eggert and Ulaga 2002), discussions of its definition, the usage of unior multi- dimensional formulation and its representation are still open. There is surprisingly little agreement between researchers in the area of value research when it comes both to theoretical outline (lack of common theory) and practical implications (contradictory findings). According to La, Patterson and Styles (2005), limited attention is given to perceived value in the context of professional business-tobusiness services. Their research proves the mediating effect of customer perceived value (CPV) on the relationship between perceived performance and customer satisfaction.

In research on customer value, significant efforts were put in defining value drivers. Lapierre (2000) attempts to identify value drivers in customer perceived value formulated as the "difference between the benefits and the sacrifices perceived by customers in terms of their expectations, i.e. needs and wants". Through qualitative research, he identifies ten different value drivers and classifies them as product-, service- and relationship-related. He shows that customers in different segments assess most of the value drivers in a similar way. This research also found that flexibility and responsiveness (service-related drivers) are important as perceived value drivers.

Roig et al. (2006) analyzed customer perceived value in banking services. Together with a number of authors (e.g. Lin, Sher and Shih 2005) they support a multidimensional perception of value through its functional (practical or cognitive) and additional dimensions (emotional and social). However, when it comes to customer value for organizational customers, a uni-dimensional approach is more often advocated. Eggert and Ulaga $(2002,110)$ define value as "the trade-off between the multiple benefits and sacrifices of a supplier's offering, as perceived by key decision-makers in the customer's organization, and taking into consideration the available alternative suppliers' offerings in a special use situation". They also proved that despite there being a strong interaction between customer value and customer satisfaction, perceived value is not a substitute for satisfaction and that they should be conceptualized and measured as two distinct constructs.

As organizational customers purchase primarily based on rational, not emotional reasons, this research regards customer perceived value as a ratio of benefits and sacrifices perceived by customers (Zeithaml 1988; Hansen, Samuelsen and Silseth 2008) or as a uni-dimensional construct.

\section{CONCEPTUAL FRAMEWORK}

Corporate reputation and information sharing are seen as intangible drivers/ antecedents of customer perceived value. The model that is analyzed in this research study is shown in Figure 1.

The corporate reputation of service companies is directly related to benefits (an increase in corporate reputation is associated with an increase of perceived benefits) and at the same time inversely related to customer sacrifices (an increase in corporate reputation is connected to a decrease in perceived costs and sacrifices). Corporate reputation decreases purchase risk (Helm and Salminen 2010; Sheehan and Stabel 2010) and when the relationship between company and customer is already established, it increases trust and identification (Keh and Xie 2009), as well as attitudinal 
and behavioral outcomes (e.g. Bartikowski and Walsh, 2011), thus it is positively related to increased perceived benefits and perceived value. This also means that if its reputation is good, a company does not need to spend additional resources in overlooking the relationship (Hansen, Samuelsen and Silseth 2008) which lowers sacrifices and therefore increases perceived value. Therefore:

H1: Corporate reputation has a positive and significant influence on customer perceived value.

The paths of information sharing and customer perceived value are conceptualized in a manner similar to that for corporate reputation. If a company is open towards its clients and offers all important information in order to create a better relationship, it is establishing more trust in their relationship (Tai and Ho 2010; Zaheer, McEvily and Perrone 1998) and therefore helping to increase perceived benefits. Frequent and relevant information sharing also decreases the costs for the client to collect such information on its own (Lee, So and Tang 2009). Therefore:

H2: Information sharing has a positive and significant influence on customer perceived value.

Information sharing is the communication effect that nurtures the partners' relationship. Corporate communication creates corporate reputation (Gray and Balmer 1998), and as information sharing is part of the corporate communication set, it should therefore influence perceived corporate reputation as well. In line with previous relationships we propose the following hypothesis:

H3: The effect of information sharing on customer perceived value is mediated by corporate reputation.

Figure 1: Impact of corporate reputation and information sharing on customer perceived value

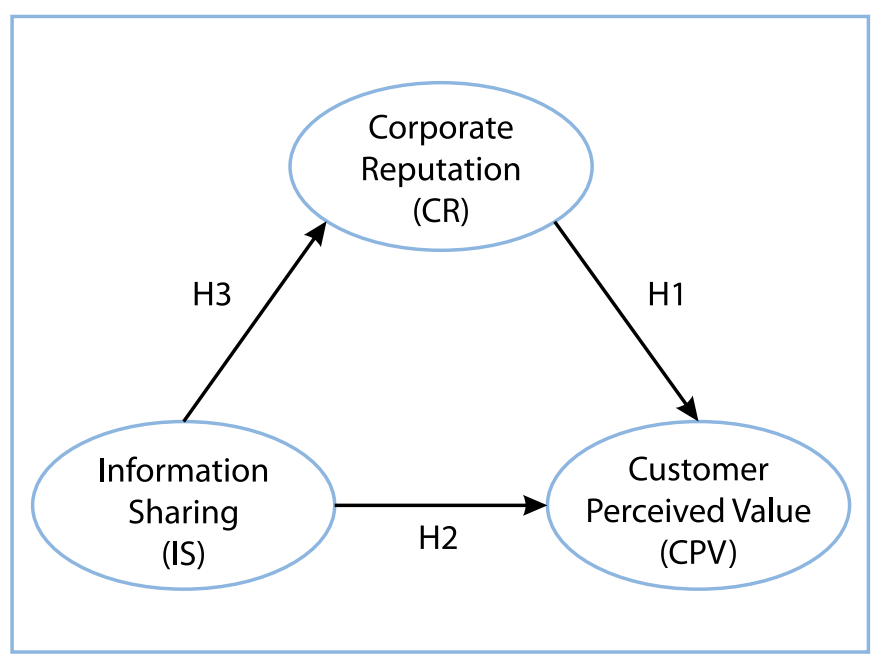

\section{METHODOLOGY \\ Measurement Development and Data Collection}

Based on the literature review and conceptual framework, an empirical test of the hypothesized model was done. Organizational customers from a South East European country shared their views about banks they selected to build a relationship with and currently cooperate with. Variables for the model were operationalized on the basis of existing operationalizations with modifications and developments in the context of business services. The research instrument contained multi-item scales and was adapted from the existing literature (Selnes 1993; Noordewier et al. 1990; Hansen, Samuelsen and Silseth 2008). The corporate reputation and information sharing scale consisted of 3 items each, while the customer perceived value scale consisted of 6 items. Additional descriptive questions were posed to the respondents. The questionnaire was refined through two stages of pre-testing with two academic and three practice experts. For control variables, the number of employees (EMP), legal status (STAT), domestic/foreign business activity (ACT), size (SZ), number of customers (NOC), and number of products/ services (NOP) were used.

Data were gathered through online and e-mail surveys, and a convenience sampling method was used. The sample framework included firms listed on the Register of Business Entities of the Foreign Trade Chamber of Bosnia and Herzegovina. A total of 646 were successfully reached and 104 questionnaires were returned with a response rate of $13 \%$. Data were gathered from the managers responsible for finance and/or accounting in 104 companies from different industry sectors. At the beginning of the survey, we stated that the key informant from the company should be the person who has day-to-day relationships with the selected bank they evaluate. These were finance/accounting managers in all of the cases. The context of bank services was chosen because it provides a good representation of organizational customers of the specialized professional service industry and includes a wide continuum of relationships from short to long term providing the desired variability of relationships (Tellefsen and Thomas 2005). The respondents were instructed to answer questions about the specific bank, bearing in mind the entire relationship they had had with that provider.

Information about the characteristics of the sample is presented in Table 1. Companies engaged in services represent $34 \%$ of the sample, while production companies represent only $19 \%$ of the sample. Most of the companies (64\%) have less than 50 employees; company size was assessed by number of employees and also by self-reported size of the revenue, hence large companies in terms of revenue represent $28 \%$ of the sample. The companies are mostly engaged in foreign trading (58\%), and $50 \%$ of the exporters are present at more than four foreign markets. In industry structure, most of companies are in wholesale and retail trading (21\%); followed by the construction sector (14\%) and IT sector $(8 \%)$. The rest of the sample is fragmented along a wide spectrum of industries such as the food industry, chemical industry, media, transport, real-estate, or agriculture. 
Table 1: Sample Characteristics

\begin{tabular}{|c|c|c|c|}
\hline \multicolumn{4}{|c|}{ Sample Characteristics } \\
\hline Type of Buseiness Activity & & Legal status & \\
\hline Production & $19.23 \%$ & limited liability & $85.58 \%$ \\
\hline Trade & $27.88 \%$ & joint stock company & $14.42 \%$ \\
\hline Services & $33.65 \%$ & & \\
\hline Combination & $19.23 \%$ & & \\
\hline Number of Employees & & Ownership & \\
\hline Less than 50 & $64.42 \%$ & Domestic & $73.08 \%$ \\
\hline 50 to 100 & $12.50 \%$ & Foreign & $15.38 \%$ \\
\hline 101 to 500 & $18.27 \%$ & Domestic and Foreign & $11.54 \%$ \\
\hline More than 500 & $4.81 \%$ & & \\
\hline Size/Revenues & & Number of Customers & \\
\hline Small (less than 2 mio EUR) & $37.50 \%$ & Less than 1,000 & $73.08 \%$ \\
\hline Medium (2 mio-20 mio EUR) & $34.62 \%$ & 1,001 to 10,000 & $19.23 \%$ \\
\hline \multirow[t]{2}{*}{ Large (more than 20 mio EUR) } & $27.88 \%$ & 10,001 to 100,000 & $1.92 \%$ \\
\hline & & More than 100,000 & $5.77 \%$ \\
\hline Domestic/Foreign Trading & & Number of Products/Services & \\
\hline Domestic and Foreign & $57.69 \%$ & Less than 10 & $26.92 \%$ \\
\hline \multirow[t]{2}{*}{ Domestic } & $43.27 \%$ & 10 to 50 & $24.04 \%$ \\
\hline & & 51 to 100 & $10.58 \%$ \\
\hline Number of Foreign Markets & & More than 100 & $38.46 \%$ \\
\hline Up to 2 & $25.00 \%$ & & \\
\hline 2 to 4 & $25.00 \%$ & & \\
\hline More than 4 & $50.00 \%$ & & \\
\hline
\end{tabular}

In order to ensure the generalizability of results on the country level, we used company size as a proxy. We scanned the structure of bank clients using available public reports for the year when the research was conducted. The top three banks hold $45 \%$ of the market share in the country $(\mathrm{CBBH}, 2011$; Deloitte, n.d.), and the cumulative size of their business segments is approx. 7,500 clients for the corporate segment and 20,000 clients for the SME segment (Raiffeisen bank, 2011; UniCredit bank, 2011; Hypo-Alpe-Adria bank, 2011). The ratio between large enterprises and SMEs is $27: 72$, which is in line with the structure of companies in the sample.

\section{Data Analysis}

We first performed a confirmatory factor analysis (CFA) to test the measurement model. We used the covariance matrix as an input to LISREL 8.8. The goodness-of-fit indices for the CFA for the model was within an acceptable range: measures of absolute fit ( $x 2=82.93, d f=60, p=0.08 ; x 2 / d f=1.3$ ), the root mean square of error of approximation (RMSEA) $=0.03$, and the standardized root mean square residual
$(\mathrm{SRMR})=0.05$ and $\mathrm{GFI}=0.91)$ indicated a good fit, as well as incremental fit measures (NFI $=0.93, \mathrm{NNFI}=0.99, \mathrm{GFI}=.91$ ) and parsimonious fit measures $(\mathrm{CFI}=0.99)$, which are acceptable values of fit indices according to Bollen (1989).

We then tested the item and construct reliability (Table 2). All items were reliable and all values for composite reliability were above the critical limit (0.60). According to a complementary measure for construct reliability, average variance extracted (AVE), all constructs demonstrated good reliability. We also tested the model for convergent and discriminant validity. Convergent validity was assessed by examining the t-test values of indicator loadings in the measurement model (Anderson and Gerbing 1988). All the $\mathrm{t}$-values of the loadings of measurement variables on respective latent variables were statistically significant. Thus, convergent validity was supported. Discriminant validity was assessed with a chi-square test for pairs of latent variables constraining the correlation coefficient between the two latent variables to 1 (Anderson and Gerbing 1988). All unconstrained models had a significantly lower value of chisquare than the constrained models (Bagozzi and Phillips 1982), hence we can conclude that the latent variables were not perfectly correlated and that discriminant validity exists. 
Table 2: Item and construct reliability

\begin{tabular}{|c|c|c|c|c|}
\hline Item & C.R. & AVE & $\lambda$ & t-value \\
\hline \multicolumn{5}{|l|}{ Customer perceived value } \\
\hline It is more valuable to us to do business with the bank than with other banks. & & & 0.803 & - \\
\hline We consider it very advantageous to be a customer of the bank. & 0.74 & 0.49 & 0.675 & 5.642 \\
\hline As a customer of the bank we get more value for money. & & & 0.599 & 5.097 \\
\hline \multicolumn{5}{|l|}{ Corporate reputation } \\
\hline The bank has a good reputation among your colleagues and friends. & & & 0.820 & - \\
\hline The bank has a good reputation compared to their competitors. & 0.88 & 0.71 & 0.911 & 9.470 \\
\hline The bank has a good reputation in the market in general. & & & 0.786 & 8.097 \\
\hline \multicolumn{5}{|l|}{ Information sharing } \\
\hline $\begin{array}{l}\text { We are often informed by the bank about issues that might relate to our } \\
\text { relationship. }\end{array}$ & & & 0.780 & - \\
\hline The bank informs us rapidly on issues that might influence our future relationship. & 0.90 & 0.74 & 0.915 & 9.956 \\
\hline $\begin{array}{l}\text { The bank informs us rapidly on issues that might influence our day-to-day } \\
\text { performance. }\end{array}$ & & & 0.883 & 9.828 \\
\hline
\end{tabular}

Model fit Chi-Square $=82.926(P=0.0266)$, d.f. $=60, \mathrm{RMSEA}=0.03, \mathrm{CFI}=0.99$, Standardized RMR $=0.05$

Note: $C . R .=$ composite reliability, $A V E=$ average variance extracted, $\lambda=$ indicator loadings.

Data were also tested for common method bias (Podsakoff and Organ 1986). We tested the presence of common method bias using Harman's single factor test. We ran a confirmatory factor analysis loading all items on one factor and compared the model fit. In both cases, the resulting one-factor measurement model had much worse fit indices than the proposed measurement model. Common method bias is therefore not present.

Structural equation modeling was used next, following the two-step approach (Anderson and Gerbing 1988), and using LISREL 8.8 (see Table 3). The fit statistics for the model indicate that the overall model has a statistically significant value for the chi-square test $(x 2=92.51, \mathrm{df}=66, \mathrm{p}$ $=0.02$ ), and the proportion between the chi-square value and degrees of freedom were within an acceptable range $(x 2 / d f=1.4)$. RMSEA $(0.03)$ shows a good and standardized RMR (0.05), which is an acceptable fit. Among other absolute measures of fit, GFI (0.90), NFI (0.92), NNFI (0.98) and parsimonious measure of fit $(\mathrm{CFI}=0.99)$ showed a good fit. Therefore, the overall fit of the model is good.

Table 3 shows the standardized path coefficients for the structural model. The parameter estimates for the relationship between corporate reputation and customer perceived value $(\mathrm{H} 1)$ is statistically significant and consistent with the proposed direction in the hypotheses. The second hypothesis ( $\mathrm{H} 2)$ on the effect of information sharing on customer perceived value is not confirmed. To test for mediation (H3), we followed the procedure outlined in Holmbeck (1997). The fit of the direct effect (information sharing - perceived value) is adequate. Since the overall model (information sharing-corporate reputation-customer perceived value) provides an adequate fit, path coefficients (information sharing-corporate reputation and corporate reputationcustomer perceived value) are examined. The fit of the model (information sharing-corporate reputation-customer perceived value) is examined under two conditions: when

Table 3: Standardized path coefficients

\begin{tabular}{|l|l|}
\hline HYPOTHESIZED PATHS & Standardized Path Coefficients \\
\hline H1: Corporate reputation - > Customer perceived value & $0.616^{* * *}$ \\
H2: Information sharing - > Customer perceived value & 0.154 \\
H3: Information sharing - > Corporate reputation & $0.518^{* * *}$ \\
\hline Control variables: & 0.208 \\
$\quad$ Number of employees & $-0.159^{* *}$ \\
Legal status & 0.074 \\
Domestic/foreign business activity & -0.107 \\
Size & 0.026 \\
Number of customers & -0.024 \\
\hline
\end{tabular}

Note: ${ }^{* *} p<0.01,{ }^{* * *} p<.001$. 
the path (information sharing-customer perceived value) is constrained to zero and when it is not constrained. The second model does not provide a significant improvement in fit over the first model (the difference in chi-square tests is 1.56 ( 1 d.f.), hence not significant). Therefore, the previously significant path (information sharing-CPV) is reduced to insignificance when the mediator of corporate reputation is taken into account. An additional Sobel test (Sobel, 1982) yielded significant results (test statistic is 3.56 , std. error = $0.068, p=0.0003$ ). In sum, the analysis revealed that reputation mediates the effect of information sharing on CPV. In terms of predictive power, exogenous variables of reputation and information sharing together with control variables (number of employees, legal status, domestic/foreign business activity, size, number of customers, and number of products/services) explain $51 \%$ of the variance in customer perceived value. The dependent variable of customer perceived value is therefore well explained by the independent and control variables.

\section{DISCUSSION AND CONCLUSIONS}

Reputation and information sharing are seen as signals that customers observe in the process of value creation, which is the end focus for corporate marketing. In this research we take the standpoint of signaling theory and empirically investigate the influence of providers' information sharing and corporate reputation on customer perceived value. Our proposed conceptual framework hence contributes to the theoretical knowledge for both signaling and customer perceived value research. Both observed signals are tied to corporate communications. This research points out that customer perceived value in the context of business service relationships is to a large degree a consequence of communication efforts.

Previous research suggests that corporate reputation and information sharing are important corporate marketing concepts that help increase value for a company's stakeholders, in our case for organizational customers (Eggert and Ulaga 2002; Hansen, Samuelsen and Silseth 2008; Powel 2011). This analysis enabled us to propose a model where both of the observed corporate marketing mix elements are hypothesized to have a positive influence on customer perceived value (CPV). Additionally, an indirect effect of information sharing on CPV, through corporate reputation as a mediator, is evident from our empirical research. In this way we help in better understanding cause and effect relationships between value antecedents and CPV.

According to empirical testing and in line with our hypothesis, corporate reputation has a positive and significant influence on customer perceived value. This finding could be interpreted to suggest that corporate reputation evolves as an important intangible antecedent of customer perceived value. The influence of corporate reputation comes as no surprise and is in line with previous research. A bank's corporate reputation therefore influences organizational customer perception about the value of the bank's service. Furthermore, as customer perceived value is linked to satisfaction and loyalty, corporate reputation can have an indirect influence also on customer satisfaction and loyalty (Eggert and Ulaga 2002; Chi, Yeh and Jang, 2008). The influence of corporate reputation on CPV could also be analyzed separately in the pre-purchase and purchase phases in the service delivery process. Before purchase, customers often do not have enough competences to estimate quality and the advantages of a specific bank's service and often rely on reputation, especially if they are using the service for the first time. Therefore, corporate reputation could serve customers as an instrument for decreasing perceived risk and for decreasing the "fear" of unwanted consequences. During the purchase, or in the case where long-term business relationships and networks already exist, good corporate reputation implies that there is a mutual trust and that established relationships will be maintained. In both cases, we see that corporate reputation leads to an increase of customer perceived value (through decreasing perceived costs/ sacrifices and increasing perceived benefits). We argue that established corporate reputation represents a competitive advantage for the company and a significant barrier to entry for new competitors.

Contrary to our expectations, the direct relationship between information sharing and CPV is not significant. Although we expected that information sharing as a form of direct communication is crucial for customer value creation, we could not find any significant direct effect in this regard. We argue that this finding is even more relevant for future research than the findings related to the first hypothesis. It is in line with the assumption that the bonding effect of information sharing is a weaker signal relative to corporate reputation. The lack of significant results for the second hypothesis leads us to additional questions: What is the purpose of information sharing as a special form of corporate communication? In what ways is information shared? What is the content of the information that is provided?

From the results obtained we cannot claim that information sharing directly influences the perceived increase of benefits and decrease of costs from a service. However, when we check for indirect influence, a relationship between customer perceived value and information sharing is indeed mediated by corporate reputation. We may even say that corporate reputation assumes a significant part of information sharing's signaling power. This result also brings a new understanding of the order of customer perceived value antecedents. Information sharing and corporate reputation are not in the same line of order. This contrasts with the findings of Hansen et al. (2008), who propose the same line of order in their study. At the same time, all antecedents except for corporate reputation are reported as either insignificant or with low loadings.

We controlled our model for different firmographic characteristics: number of employees, legal status, domestic/foreign business activity, size, number of customers, and number of products/services. None of the variables except for legal status turned out to be significant in our model. This shows that the proposed model relationships are consistent across different groups in the sample, except for the legal status related groups. Our sample was comprised of limited 
liability and joint stock companies. Joint stock companies perceive the signals from banks differently than limited liability companies. We conclude that the influence of corporate reputation on customer perceived value and the indirect effect of information sharing on customer perceived value are lower for joint stock companies than for limited liability companies, which is interesting due to the fact that banks tend to devote much more attention to joint stock companies (constituting the so-called "corporate" section in banks) than to limited liability companies. We may conclude that joint stock companies to a higher degree take corporate reputation and information sharing signals for granted and hence the effect of these signals is not as strong as it is in the case of limited liability companies.

The practical implications of this paper for service companies are multiple: when creating a strategy and throughout its implementation based on elements of the corporate marketing framework, it is necessary to take into account customer perceived value. Customers, both individual and organizational, assess what they receive and compare it with what they invest. Service companies should evaluate whether this assessment is in line with what is aimed at from the company's side. This is especially important because CPV is also used as a basis for the decision whether to stay with the company or to search for alternatives (Hansen, Samuelsen and Silseth 2008). Based on our empirical findings we can argue that the influence of corporate reputation on CPV is unquestionable and that service companies should put maximum effort into building, managing, maintaining and improving their reputation. On the other hand, information sharing is not significant for CPV directly, which poses several additional questions outlined in the discussion. Certainly, finding answers to these questions requires more research and additional qualitative insights.

Although we were able to explain a significant amount of variance in CPV and controlled for the size of companies in terms of number of employees, their legal status, domestic/foreign business activity, number of customers, and the number of products/services they offer, the study is still limited to two of the six Cs of corporate marketing. The present research also has limitations in terms of the size of the sample. Hence, new surveys should be conducted with a broader scope and could possibly include comparisons between countries and among different service provider industries aside from banks, as in the present case.

\section{REFERENCES}

Anderson, J. C. and Gerbing, D. W. 1988. Structural equation modeling in practice: A review and recommended two-step approach. Psychological Bulletin 103 (3): 411-423.

Argenti, P. A., Howell, R. A. and Beck. K.A. 2005. The strategic communication imperative. MIT Sloan Management Review 46(3): 83-87.

Bagozzi, R. P. and Phillips, L. W. 1982. Representing and Testing Organizational Theories: A Holistic Construal. Administrative Science Quarterly 27(September): 459-489.
Balmer, J. M.T. 1998. Corporate identity and the advent of corporate marketing. Journal of Marketing Management 14(8): 963-996.

Balmer, J. M.T. 2006. Comprehending corporate marketing and the corporate marketing mix. Working Paper Series, working paper 06/08. Bradfort School of Management. Bradford: University of Bradford.

Balmer, J. M.T. and Greyser, S. A. 2006. Corporate marketing: integrating corporate identity, corporate branding, corporate communications, corporate image and corporate reputation. European Journal of Marketing 40(7/8): 730-741.

Balmer, J. M.T. 2009.Corporate marketing: apocalypse, advent and epiphany. Management Decision 47(4): 544-572.

Balmer, J. M.T. 2011. Corporate marketing myopia and the inexorable rise of a corporate marketing logic: Perspectives from identity-based views of the firm. European Journal of Marketing 45(9/10): 1329-1352.

Banerjee, D. S., \& Gaston, N. (2004). Labour market signalling and job turnover revisited. Labour Economics, 11(5), 599-622.

Bartikowski, B., \& Walsh, G. (2011). Investigating mediators between corporate reputation and customer citizenship behaviors. Journal of Business Research, 64(1), 39-44. doi:10.1016/j. jbusres.2009.09.018

Baron, R. M., and Kenny, D. A. 1986. The moderator-mediator variable distinction in social psychological research: Conceptual, strategic and statistical considerations. Journal of Personality and Social Psychology, 51: 1173-1182.

Bengtsson, A. and Servais, P. 2005. Co-branding on industrial markets. Industrial Marketing Management 34(7): 706-713.

Bollen, K. A.1989. Structural equations with latent variables. New York: John Wiley \& Sons.

Bourdieu, P. (1985). The forms of capital. In J.G. richardson (Ed.), Handbook of Theory and Research of for the Sociology of Education (p.p. 241-258). New York: Greenwood.

Cannon, J. P. and Homburg, C. 2001. Buyer-Supplier Relationship and Customer Firm Costs. Journal of Marketing, 65(1): 29-43.

Cannon, J. P. and Perreault, W. D. Jr. 1999. Buyer-seller relationships in business markets. Journal of Marketing Research 36(November): 439-460.

Centralna banka Bosne i Hercegovine. 2011. Godišnji izvještaj 2011. [Annual report 2011]. Sarajevo: Centralna banka Bosne i Hercegovine.

Chi, H. K., Yeh, H.R. and Jang. B.F. 2008. The Effects of Service Quality, Customer Perceived Value, Customer Satisfaction on Behavioral Intentions: A Study of Mobile Value-Added Services in Taiwan. The Business Review, Cambridge, 10(2008): 129-136.

Christensen, L. T. and Cornelissen, J. 2010. Bridging Corporate and Organizational Communication: Review, Development and a Look to the Future. Management Communication Quarterly, 25 (2010): 383-414

Deephouse, D. L. 2000. Media reputation as a strategic resource: An integration of mass communication and resource-based theories. Journal of Management 26(6): 1091-1112.

Deloitte. n.d.. Vodeće banke i osiguravatelji u Adria regiji [Leading banks and insurances in Adria region]. Retreived February 6, 2013, from http://www.deloitte.com/view/hr_HR/hr/industrije/financijskaindustrija/problematikaitrendovi/3e8c6237c53f0 310VgnVCM3000001c56f00aRCRD.htm. 
Donaldson, T. and Preston, L. E. 1995. The Stakeholder Theory of the Corporation: Concepts, Evidence, and Implications. Academy of Management Review, 20: 65-91.

Eggert, A. and Ulaga, W. 2002. Customer Perceived Value: a Substitute for Satisfaction in Business Markets. Journal of Business \& Industrial Marketing 17(2/3): 107-118.

Fombrun, C. J. 1996. Reputation: Realizing Value from the Corporate Image. Boston: Harvard Business School Press.

Fombrun, C.J. and Van Riel, C.B.M. 1997. The Reputational Landscape. Corporate Reputation Review 1(1/2): 5-13.

Fornell, C., Johnson, M.D., Anderson, E.W., Cha, J. and Everitt Bryant, B. 1996. The American customer satisfaction index: nature, purpose and findings. Journal of Marketing 60(4): 7-18.

Freeman, R. E. 1984. Strategic management: a stakeholder approach. Boston: Ptiman.

Frow, P. and Payne, A. 2011. A Stakeholder Perspective of the Value Proposition Concept. European Journal of Marketing, 45(1/2): 223-240.

Gray, E. R. and Balmer, J. M. T. 1998. Managing Corporate Image and Corporate Reputation. Long Range Planning, 31(5): 695-702.

Gummesson, E. 2008. Extending the Service-dominant Logic: From Customer Centricity to Balanced Centricity. Journal of the Academy of Marketing Science, 36(2008): 15-17.

Hansen, H., Samuelsen, B.M. and Silseth, P.R.. 2008. Customer Perceived Value in B-t-B Service Relationships: Investigating the Importance of Corporate Reputation. Industrial Marketing Management, 37: 206-217.

Helm, S. 2007. The Role of Corporate Reputation in Determining Investor

Satisfaction and Loyalty. Corporate Reputation Review, 10(1): 22-37.

Helm, S. and Salminen, R.T.. 2010. Basking in Reflected Glory: Using Customer Reference Relationships to Build Reputation in Industrial Markets. Industrial Marketing Management, 39(5): 737-743.

Holmbeck, G. N. 1997. Toward terminological, conceptual, and statistical clarity in the study of mediators and moderators: examples from the child-clinical and pediatric psychology literatures. Journal of consulting and clinical psychology, 65(4): 599-610.

Holbrook, M. B. 1994. The nature of customer value. In: Rust RT, Oliver R (eds)

Service quality: new directions in theory and practice. London: Sage Publications.

Hypo Alpe Adria bank. 2011. Godišnje izvješće 2011. [Annual report 2011]. Mostar: Hypo Alpe Adria bank.

Ippolito, P. M. 1990. Bonding and Nonbonding Signals of Product Quality. The Journal of Business, 63(1): 41-60.

Jonsson, S. and Lindbergh, J. 2010. The Impact of Institutional Impediments and Information and Knowledge Exchange on SMEs' Investments in International Business Relationships. International Business Review 19(6): 548-561.

Keh, H. T. and Xie, Y. 2009. Corporate Reputation and Customer Behavioral Intentions: The Roles of Trust, Identification and Commitment. Industrial Marketing Management 38(2009): 732-742.

Kirmani, A. and Rao, A.R. 2000. No Pain, No Gain: A Critical Review of the Literature on Signaling Unobservable Product Quality, Journal of Marketing, 64(April): 66-79.
Kolekofski, K. Jr and Heminger, A.R.E. 2003. Beliefs and Attitudes Affecting Intentions to Share Information in an Organizational Setting, Information \& Management 40: 521-532.

Krause, D. R. 1999. The antecedents of buying firms' efforts to improve suppliers. Journal of Operations Management 17(2): 205-224.

La, V. Q., Patterson, P.G. and Styles, C.W. 2005. ISBM Report 172005: Client Perceived Value in Professional B2B Services - An International Perspective in Developing Economies.Institute for the Study of Business Markets The Pennsylvania State University.

Lapierre, J. 2000. Customer-perceived Value in Industrial Contexts. Journal of Business \& Industrial Marketing 15(2/3): 122-140.

Lee, H. L., So, K.S. and Tang, C.S. 2000. The value of information sharing in a two-level supply chain. Management Science 46(5): 626-643.

Lin, C.H., Sher, P.J. and Shih, H.Y. 2005. Past Progress and Future Directions in Conceptualizing Customer Perceived Value. International Journal of Service Management 16(3/4): 318-336.

Lusch, R. F., Vargo, S.L. and Malter, A.J. 2006. Marketing as ServiceExchange: Taking a Leadership Role in Global Marketing Management. Organizational Dynamics, 35(3): 264-278.

Noordewier, T.G., John, G. and Nevin, J.R. 1990. Performance outcomes of purchasing arrangements in industrial buyer-vendor relationships. The Journal of Marketing 54(4): 80-93.

Podsakoff, P. M. and Organ, D.W.. 1986.Self-reports in organizational research: Problems and prospects. Journal of Management 12(4): 531-544.

Powell, S. M. 2011. The Nexus between Ethical Corporate Marketing, Ethical Corporate Identity and Corporate Social Responsibility: An Internal Organisational Perspective. European Journal of Marketing, 45(2011): 1365-1379.

Raiffeisen bank dd. 2011. Godišnji izvještaj 2011 [Annual report 2011]. Sarajevo: Raiffeisen bank dd.

Roig, J. C. F., Garcia, J.S. Moliner Tena, M.A. and Monzonis, J.L. 2006. Customer perceived value in banking services. International Journal of Bank Marketing 24(5): 266-283.

Selnes, F. 1993. An examination of the effect of product performance on brand reputation, satisfaction and loyalty. European Journal of Marketing, 27(9): 19-35.

Shamma, H. M. and Hassan, S.S. 2009. Customer and Non-customer Perspectives for Examining Corporate Reputation. Journal of Product \& Brand Management 18(5): 326-337.

Sheehan, N. T. and Stabell, C.B. 2010. Reputation as a Driver in Activity Level Analysis: Reputation and Competitive Advantage in Knowledge Intensive Firms. Corporate Reputation Review 13(2010): 198-208.

Shelby, A.N. 1993. Organizational, business, management, and corporate communication: An analysis of boundaries and relationships. Journal of Business Communication 30: 241-267.

Sobel, M. E. 1982. Asymptotic confidence intervals for indirect effects in structural equation models. In S. Leinhardt (Ed.), Sociological Methodology 1982 (pp. 290-312). Washington DC: American Sociological Association.

Spence, M. 1973. Job marketing signaling. Quarterly Journal of Economics 87(3): 355-374.

Spence, M. 2002. Signaling in Retrospect and the Informational Structure of Markets. The American Economic Review, 92: 434-459. 
Stahl, H. K., Matzler, K. and Hinterhuber, H.H. 2003. Linking Customer Lifetime Value with Shareholder Value. Industrial Marketing Management 32(4): 267-279.

Tai, Y.M. and Ho, C.F. 2010.Effects of Information Sharing on Customer Relationship Intention. Industrial Management \& Data Systems 110(9): 1385-1401.

Tai, Y.M. 2011. Perceived Value for Customers in Information Sharing Services. Industrial Management \& Data Systems 111(4): 551-569.

Tellefsen, T. and Thomas, G.P. 2005. The antecedents and consequences of organizational and personal commitment in business service relationships. Industrial Marketing Management 34: 23-37.

Tiedemann, N., Van Birgele, M. and Semeijn, J. 2009. Increasing Hotel Responsiveness to Customers through Information Sharing. Tourism Review 64(4): 12-26.

UniCredit bank dd. 2011. Godišnje izvješće za 2011. godinu [Annual report for year 2011]. Mostar: UniCredit bank dd.

Van Riel, C. B.M. 1995. Corporate Communication. New York: Prentice Hall.

Vargo, S. L. and Lusch, R.F. 2004. Evolving to a New Dominant Logic. Journal of Marketing 68(2004): 1-17.
Vargo, S. L. and Lusch, R.F. 2007. Service-dominant Logic: Continuing the Evolution. Journal of the Academy of Marketing Science 36(1): 1-10.

Vermaelen, T. 1981. Common stock repurchases and market signalling: An empirical study. Journal of Financial Economics, 9(2): 139-183.

Walker, K. 2010. A Systematic Review of the Corporate Reputation Literature: Definition, Measurement, and Theory. Corporate Reputation Review 12(4): 357-387.

Wernerfelt, B. 1988. Umbrella branding as a signal of new product quality: an example of signalling by posting a bond. The RAND Journal of Economics 19(3): 458-466.

Wiedmann, K.P. and Buxel, H. 2005. Corporate reputation management in

Germany: results of an empirical study. Corporate Reputation Review 8(2): 145-163.

Zaheer, A., McEvily, B., \& Perrone, V. 1998. Does trust matter? Exploring the effects of interorganizational and interpersonal trust on performance. Organization Science, 9(2): 141-159.

Zeithaml, V. A. 1988. Consumer Perceptions of Price, Quality, and Value: a Means-end Model and Synthesis of Evidence. The Journal of Marketing 52: 2-22. 